\title{
Insulin-resistance-associated compensatory mechanisms of pancreatic beta cells: a current opinion
}

\author{
Tiago G. Araújo, Alexandre G. Oliveira and Mario J. A. Saad* \\ Department of Internal Medicine, State University of Campinas, Campinas, São Paulo, Brazil \\ *Correspondence: msaad@fcm.unicamp.br \\ Edited by: \\ Anca Dana Dobrian, Eastern Virginia Medical School, USA
}

Keywords: HGF, betatrophin, liver, beta cells, insulin-resistance, diabetes mellitus, obesity

In obesity and in most situations of insulin-resistance, $\beta$-cells compensate for this hormonal resistance for long periods of time by an increase in secretory capacity and in $\beta$-cell mass. In animal models of insulin-resistance there is islet hyperplasia (1-3) and very recently a clear correlation between BMI and $\beta$-cells mass was shown in humans (4). The driving forces that can contribute to the increased $\beta$-cell mass in insulin-resistant states are not completely understood. It is well-established that glucose itself is able to induce $\beta$-cell hyperplasia $(3,5)$. However in many situations of insulin-resistance the hyperplastic response comes prior to any change in circulating glucose levels, indicating that other factors independent of glucose may contribute to the islet hyperplasia. Among circulating hormones and/or growth factors such as growth hormone $(\mathrm{GH})$, insulin-like growth factor I (IGF-I), prolactin, and placental lactogen were implicated in islet hyperplasia associated with insulin-resistance. However, some data does not support the contribution of these hormones in islet hyperplasia. For example, GH and IGF-I were not altered in diet-induced obesity (DIO) mice and most insulin-resistant animal models investigated were male, making prolactin and the placental lactogen improbable candidates. In the past 4 years a novel pathway involving a neural relay and two hormones - betatrophin and hepatocyte growth factor (HGF) - were implicated as an inter-organ communication system associated to the compensatory response of $\beta$ cells in face of insulin-resistance (6-8). In this commentary we will focus on evidence showing the role of this novel pathway in islet hypertrophy associated with obesity and insulin-resistance.

In a recent publication by $\mathrm{Yi}$ and collaborators (8), the authors identified betatrophin, a novel hormone that increases in insulin-resistant states and controls pancreatic $\beta$ cell proliferation. This hormone was recognized through the infusion in mice of the insulin receptor antagonist (S961) able to induce insulin-resistance, and also provoke at a dose-dependent manner a dramatic pancreatic $\beta$ cell proliferation. By microarray, they identified the hormone betatrophin from the liver and adipose tissue of these animals, which showed that it is able to induce beta cell proliferation. In addition, the authors also demonstrated that the betatrophin mRNA was increased in the liver from $o b / o b$ and $d b / d b$ mice (three to four-fold), as well as during the mice pregnancy ( 20 -fold). As discussed below, HGF is a growth factor that plays a key role in regulation of islet mass increases along with hyperinsulinemia in animal models of insulin-resistance, therefore could also play a role, however, this possibility was not addressed by Yi et al. (8). Additional aspects of the work deserve further clarification, although Yi et al. showed a possible cause-effect relationship between betatrophin and an increase in pancreatic $\beta$ cell proliferation in their approach, some aspects were not thoroughly clarified. For example, they did not demonstrate the correlation between circulating levels of betatrophin and the increase in islet mass; most of the experiments are in an artificial model of insulin-resistance, based on the use of an insulin receptor antagonist, and not in the traditional models of obesity and or insulin-resistance, mainly based on a diet-induced obesity $(9,10)$; and, the increase in mRNA of betatrophin is much higher in pregnancy than in $o b / o b$ and $d b / d b$ mice, but the increase in islet mass is usually higher in these genetic models compared to pregnancy $(1,11)$. In addition, the regulations of complex processes that are evolutionary conserved and/or adaptive traits, such as insulin-resistance is usually involve redundant mechanisms. In this regard, an important point we would like to emphasize is that the compensatory increase in islet cell mass and hyperinsulinemia is multifactorial and involves central nervous system (CNS) (7), and at least one more growth factor besides betatrophin, this one known as HGF, as we previously demonstrated (6).

Imai and coworkers identified a neuronal relay, originating in the liver, which enhances both insulin secretion and pancreatic $\beta$-cell proliferation (7). They showed that blocking this neural relay in rodent obesity models led to an inhibition in pancreatic islet expansion during obesity development, presenting this inter-organ communication system to be physiologically involved in compensatory $\beta$-cell proliferation. This neuronal relay is connected with signaling pathways in the liver, since it is triggered by an increase in the phosphorylation of hepatic extracellular signal-regulated kinase (ERK), which is known to be activated in the liver of a murine obesity model (12). Thus, through an adenoviral gene transduction approach that promoted a liver-selective expression of a constitutively active mutant of mitogen-activated protein kinase/ERK kinase (MEK-1), they were able to induce insulin hypersecretion and $\beta$-cell proliferation. Moreover, they also demonstrated that these pancreatic effects of hepatic ERK activation were inhibited by splanchnic afferent blockade, pancreatic vagus dissection, or midbrain transection (7).

Kahn's group has consistently showed that circulating growth factors, probably produced by the liver, are also important in the connection between insulin-resistance and the increase in islet mass $(1,2)$. Also, our group recently published a study (6) that presented the HGF as one of the systemic liver-derived growth factors that plays 


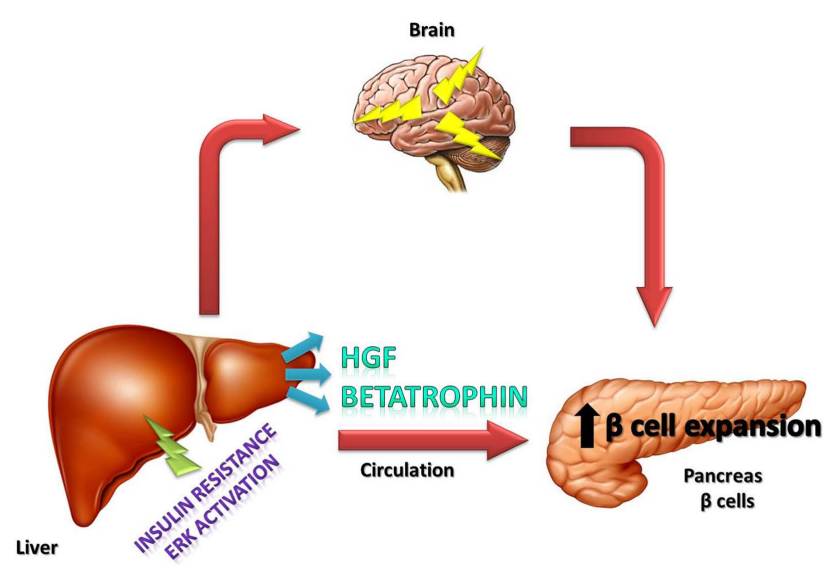

FIGURE 1 | Schematic representation of the effects of betatrophin and HGF hormones, as well as, neural circuits on islets in which these components together induce the compensatory response to insulin-resistance.

a role in insulin-resistance compensatory mechanism through the liver-to-pancreas axis in the adaptive $\beta$ cell growth response. The concept of the study, initially, was that since it is well-established that the HGF is a mesenchymal-derived pleiotropic cytokine that regulates cell proliferation, anti-apoptosis, motility, and morphogenesis, suggests that HGF may be a good candidate of circulating insulin-resistance-related $\beta$-cell growth factor. Moreover, HGF has at least four characteristics that suggest a pathophysiological link between insulinresistance and islet hyperplasia/hyperinsulinemia: (1) HGF is mainly produced by the liver; (2) it is under the regulation of the ERK pathway; (3) HGF stimulates insulin secretion and increased islet mass both in vitro and in vivo; and (4) circulating levels are elevated in obesity associated-insulinresistance. Based on this circumstantial evidence, we studied the role of HGF in insulin-resistance compensatory mechanisms. Our approach aimed to show a possible causal relationship between an increase in circulating HGF levels and compensatory islet hyperplasia/hiperinsulinemia. In this sense, we investigated the association in a dose-dependent, longitudinal approach. Our findings showed the following: (1) there is a strong and consistent correlation between HGF and the compensatory mechanism from $\beta$-cells in three animal models of insulin-resistance; (2) that HGF increases $\beta$-cell mass in a dose-dependent manner; (3) blocking HGF shuts down the compensatory mechanisms; and (4) an increase in HGF levels seems to precede the compensatory response associated with insulinresistance, indicating that these events occur in a causal fashion. Additionally, blockages of HGF receptor (Met) worsen the already impaired insulin-induced insulin signaling in the liver of diet-induced obesity rats.

In conclusion, it is important to emphasize that the recently described betatrophin is a hormone that has an important role in the connection between insulin-resistance and increased $\beta$-cell mass, but other growth factors such as HGF and also neural circuits certainly play an important role in this process (Figure 1). The contribution of each of these factors in different situations of insulinresistance, such as in pregnancy, obesity, and type 2 diabetes, deserves further investigation.

\section{ACKNOWLEDGMENTS}

This work was supported by grants from Fundação de Amparo à Pesquisa do Estado de São Paulo (FAPESP) and Conselho Nacional de Pesquisa (CNPq) (Instituto Nacional de Ciência e Tecnologia-Obesidade e Diabetes).

\section{REFERENCES}

1. Flier SN, Kulkarni RN, Kahn CR. Evidence for a circulating islet cell growth factor in insulin-resistant states. Proc Natl Acad Sci US A (2001) 98(13):747580. doi: $10.1073 /$ pnas. 131192998
2. El Ouaamari A, Kawamori D, Dirice E, Liew CW, Shadrach JL, Hu J, et al. Liver-derived systemic factors drive beta cell hyperplasia in insulin-resistant states. Cell Rep (2013) 3(2):401-10. doi: 10.1016/j. celrep.2013.01.007

3. Ashcroft FM, Rorsman P. Diabetes mellitus and the beta cell: the last ten years. Cell (2012) 148(6):1160 71. doi: 10.1016/j.cell.2012.02.010

4. SaishoY, Butler AE, Manesso E, Elashoff D, Rizza RA, Butler PC. Beta-cell mass and turnover in humans: effects of obesity and aging. Diabetes Care (2013) 36(1):111-7. doi: 10.2337/dc12-0421

5. Bonner-Weir S, Smith FE. Islet cell growth and the growth factors involved. Trends Endocrinol Metab (1994) 5(2):60-4. doi: 10.1016/1043-2760(94)90003-5

6. Araujo TG, Oliveira AG, Carvalho BM, Guadagnini D, Protzek AO, Carvalheira JB, et al. Hepatocyte growth factor plays a key role in insulin resistance-associated compensatory mechanisms. Endocrinology (2012) 153(12):5760-9. doi: 10.1210/ en.2012-1496

7. Imai J, Katagiri H, Yamada T, Ishigaki Y, Suzuk T, Kudo H, et al. Regulation of pancreatic beta cell mass by neuronal signals from the liver. Science (2008) 322(5905):1250-4. doi: 10.1126/ science. 1163971

8. Yi P, Park JS, Melton DA. Betatrophin: a hormone that controls pancreatic beta cell proliferation. Cell (2013) 153(4):747-58. doi: 10.1016/j. cell.2013.04.008

9. Kinsey-Jones JS, Murphy KG. Current models and strategies in the development of antiobesity drugs. Ann N Y Acad Sci (2011) 1245:3-6. doi: 10.1111/j.1749-6632.2011.06343.x

10. Nilsson C, Raun K, Yan FF, Larsen MO, TangChristensen M. Laboratory animals as surrogate models of human obesity. Acta Pharmacol Sin (2012) 33(2):173-81. doi: 10.1038/aps.2011.203

11. Kim A, Miller K, Jo J, Kilimnik G, Wojcik P, Hara M. Islet architecture: a comparative study. Islets (2009) 1(2):129-36. doi: 10.4161/isl.1.2.9480

12. Yan SQ, Lin HZ, Hwang JW, Chacko VP, Diehl AM. Hepatic hyperplasia in noncirrhotic fatty livers: is obesity-related hepatic steatosis a premalignant condition? Cancer Res (2001) 61(13):5016-23.

Received: 20 August 2013; accepted: 28 September 2013; published online: 14 October 2013.

Citation: Araújo TG, Oliveira AG and Saad MJA (2013) Insulin-resistance-associated compensatory mechanisms of pancreatic beta cells: a current opinion. Front. Endocrinol. 4:146. doi: 10.3389/fendo.2013.00146

This article was submitted to Diabetes, a section of the journal Frontiers in Endocrinology.

Copyright (c) 2013 Araujo, Oliveira and Saad. This is an open-access article distributed under the terms of the Creative Commons Attribution License (CC BY). The use, distribution or reproduction in other forums is permitted, provided the original author(s) or licensor are credited and that the original publication in this journal is cited, in accordance with accepted academic practice. No use, distribution or reproduction is permitted which does not comply with these terms. 